\begin{tabular}{|l|l|l|l|l|l}
\hline Int.J.Curr.Microbiol.App.Sci (2018) 7(11): 1136-1145 \\
$\begin{array}{l}\text { International Journal of Current Microbiology and Applied Sciences } \\
\text { ISSN: 2319-7706 Volume 7 Number 11 (2018) } \\
\text { Journal homepage: http://www.ijcmas.com }\end{array}$ \\
\hline $\begin{array}{l}\text { EXCELLENT } \\
\text { PUBLISHERS }\end{array}$
\end{tabular}

\title{
Phytochemical and Nutritional Composition of Different Parts of Garden Cress (Lepidium sativum L.)
}

\author{
Satya Shree Jangra* and Vinod Kumar Madan \\ Medicinal, Aromatic and Potential Crops Section, Old IATTE Building, CCS Haryana \\ Agricultural University, Hisar-125004 (Haryana), India \\ *Corresponding author
}

\begin{tabular}{|c|c|}
\hline \multicolumn{2}{|r|}{ A B S T R A C T } \\
\hline & \multirow{10}{*}{$\begin{array}{l}\text { Traditional medicines of plant origin have become the alternative remedies to treat human } \\
\text { as well as animal ailments. People rely on medicinal plants due to their faith in traditional } \\
\text { healing process. One of traditional medicinal plant rich in nutrients is garden cress } \\
\text { (Lepidium sativum L.). Despite ubiquitous occurrence, people know very little about this } \\
\text { nature's creation of a treasure trove of nutrients. The present study was undertaken to } \\
\text { investigate the proximate, mineral and chemical composition of different parts viz. seeds, } \\
\text { aerial parts and roots of garden cress (Lepidium sativum L.) collected from two different } \\
\text { locations i.e. Hisar and Solan. Results revealed that all parts of garden cress were found to } \\
\text { have good proximate composition. On the basis of calorific value, all parts of garden cress } \\
\text { collected from both locations were found to be very rich sources of energy. Seeds, aerial } \\
\text { parts and roots of garden cress contained significant amount of minerals viz. Fe, Cu, Zn } \\
\text { and Mn. Different parts of garden cress also contained ascorbic acid, starch, tannins, total } \\
\text { sugars, reducing sugars and non-reducing sugars in varying amounts. Hence, this treasure } \\
\text { trove plant could have the potential in various pharmaceutical formulations. }\end{array}$} \\
\hline Keywords & \\
\hline Lepidiu & \\
\hline & \\
\hline Article Info & \\
\hline & \\
\hline $\begin{array}{l}\text { Accepted: } \\
10 \text { October } 2018\end{array}$ & \\
\hline Available Onli & \\
\hline & \\
\hline & \\
\hline
\end{tabular}

\section{Introduction}

In a society increasingly concerned with health and nutrition, medicinal plants emerge as alternative to synthetic products. They are used not only in traditional medicine but also in a number of food and pharmaceutical products, due to their nutritional properties and bioactivity which may be attributed to the presence of several chemical constituents (Phillipson, 2007).

Lepidium sativum L., commonly known as garden cress, is an important medicinal crop in
India. It is a fast growing edible herbaceous plant genetically related to water cress and mustard sharing their peppery, tangy flavour and aroma. It is a member of family Brassicaceae and cultivated all over India, North America and parts of Europe. Garden cress is known as asalio or chandrasur in India. In some regions, garden cress is known as garden pepper cress, pepperwort, pepper grass or poor men's pepper. Seeds, leaves and roots are economically important, however, the crop is mainly cultivated for seeds. Major bioactive constituents of garden cress include alkaloids, flavonoids, tannins, glucosinolates, 
sterols, triterpenes, saponins, anthracene glycosides, carbohydrates, proteins and phenolics (Manohar et al., 2012; Ahamad et al., 2015) which are responsible for its various ethno-pharmacological activities.

In India, the herb is generally regarded as a cure for bleeding piles, asthma, menstrual disorders and dysentery (Sharma and Agarwal, 2011). The seeds are considered aphrodisiac, depurative, emmenagogue and galactogogue. They are also used for the treatment of dyspepsia, leucorrhoea, diarrhoea, seminal weakness and scurvy. Seeds possess significant antipyretic, anti-inflammatory and coagulant activities (Al-Yahya et al., 1994). Therefore, the objective of the present study was to analyze the proximate, mineral and chemical composition of different parts viz. seeds, aerial parts and roots of garden cress (Lepidium sativum L.) collected from two different regions.

\section{Materials and Methods}

\section{Plant material}

Seeds, aerial parts and roots of garden cress (Lepidium sativum L.) were procured from the experimental area of Medicinal, Aromatic and Potential Crops Section, Department of Genetics and Plant Breeding, CCS Haryana Agricultural University, Hisar, Haryana and from the Medicinal and Aromatic Research Farm, Department of Forest Products, College of Forestry, Dr. Yashwant Singh Parmar University of Horticulture and Forestry, Nauni, Solan, H.P.

\section{Proximate analysis}

\section{Estimation of moisture content}

Two gram of the powdered samples of seeds, aerial parts and roots of garden cress were taken in three replications and dried initially at $80-90^{\circ} \mathrm{C}$ and finally at $100-102^{\circ} \mathrm{C}$. Weights of dried samples were noted until constant weights were obtained. The percentage of moisture content was calculated as follows:-

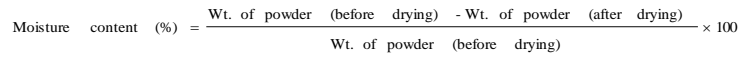

\section{Estimation of fat}

Two gram of the dried powdered samples of seeds, aerial parts and roots of garden cress were taken in a thimble and placed in a soxhlet extractor. A dried and pre-weighed round-bottomed flask $(250 \mathrm{~mL})$ was connected to the soxhlet assembly. Then petroleum ether was added up to one and a half siphons i.e. approximately 150-175 mL. The assembly was heated and extraction was carried out for $8 \mathrm{~h}$. After extraction, petroleum ether was evaporated from the roundbottomed flask and weight of the round bottomed flask along with the extract was determined again. The crude fat (\%) contents were calculated using the following formula:

Fat content $(\%)=\frac{\text { Weight of fat }}{\text { Weight of sample }} \times 100$

\section{Estimation of ash}

Two gram of the powdered samples of seeds, aerial parts and roots of garden cress were weighed and transferred into previously ignited and weighed crucible and placed in a muffle furnace (preheated at $600^{\circ} \mathrm{C}$ ) for $2 \mathrm{~h}$.

The crucibles with the samples were transferred directly from the furnace into a desiccator, allowed to cool and weight was taken. The ash contents (\%) were calculated using the following formula:

Ash content $(\%)=\frac{\text { Weight of ash }}{\text { Weight of sample }} \times 100$ 


\section{Estimation of protein}

Nitrogen and crude protein content in the powdered samples of garden cress were estimated by following conventional microKjeldahl's method. $100 \mathrm{mg}$ powdered samples of seeds, aerial parts and roots of garden cress were weighed and transferred to $100 \mathrm{~mL}$ micro-Kjeldahl's digestion flasks. About $1 \mathrm{~g}$ of $\mathrm{K}_{2} \mathrm{SO}_{4}: \mathrm{CuSO}_{4} \quad$ (9:1) was added to it followed by $10 \mathrm{~mL}$ conc. $\mathrm{H}_{2} \mathrm{SO}_{4}$. The flasks were then kept in an inclined position on the hot plate in the digestion chamber and heated gently till the solution became transparent giving a bluish green colour. After cooling, the contents of the flask were mixed with distilled water, cooled, transferred to $100 \mathrm{~mL}$ volumetric flask and volume was made up to the mark with distilled water. $10 \mathrm{~mL}$ of N/100 $\mathrm{H}_{2} \mathrm{SO}_{4}$ was taken in a conical flask which acts as a receiving flask. This flask was placed in such a way that outlet of the condenser of micro-Kjeldahl's distillation apparatus dips into the acid solution. Then, $10 \mathrm{~mL}$ of acid digested sample was transferred to the steam chamber of micro-Kjeldahl's apparatus followed by $10 \mathrm{~mL}$ of $40 \% \mathrm{NaOH}$. Immediately, the stopcock was closed, steam was passed through the steam chamber and ammonia was distilled till $30-40 \mathrm{~mL}$ of distillate was collected in the receiving flask. Receiving flask was removed and the contents were titrated against $\mathrm{N} / 100 \mathrm{NaOH}$ and volume of $\mathrm{NaOH}$ used was noted. The end-point was reached when colour changed from pink to yellow. A blank was also run simultaneously which has been digested and distilled in similar manner. Protein content was calculated as follows:

Amount of nitrogen $(\%)=(\mathrm{A}-\mathrm{B}) \times 1.4$

Where,

$A=$ Volume of $\mathrm{N} / 100 \mathrm{NaOH}$ used for blank $(\mathrm{mL})$
$\mathrm{B}=$ Volume of $\mathrm{N} / 100 \mathrm{NaOH}$ used for sample $(\mathrm{mL})$

Protein content $(\%)$ in sample $=$ Nitrogen content in sample x 6.25

\section{Estimation of crude fibre}

Crude fibre was estimated by the modified method of Maynard (1970). One gram of moisture and fat free powdered samples of seeds, aerial parts and roots of garden cress were weighed and transferred to the spoutless one litre beaker and added $200 \mathrm{~mL}$ of $1.25 \%$ $(\mathrm{w} / \mathrm{v})$ sulphuric acid. The beaker was then placed on hot plate and allowed to reflux for 30 min timed from onset of boiling and the contents were shaked after every $5 \mathrm{~min}$. After boiling for 30 min beaker was removed from hot plate and filtered through a muslin cloth using suction. The residue was washed with hot water till it became free from acid, then the material was transferred to the same beaker and added $200 \mathrm{~mL}$ of $1.25 \% \mathrm{NaOH}$ solution and the contents were again refluxed for $30 \mathrm{~min}$. It was filtered again through muslin cloth with the help of vacuum or suction pump and the residue was washed with hot water till it became free from alkali. The residue was then transferred to a crucible and placed in hot air oven, allowed to dry to constant weight at $80-110^{\circ} \mathrm{C}$ and recorded its weight. The residue was ignited in muffle furnace at $550-660^{\circ} \mathrm{C}$ for $2-3 \mathrm{~h}$, then cooled and weighed again. The loss of weight due to ignition is weight of crude fibre. The crude fibre contents (\%) were calculated using the following formula:

Crude fibre content $(\%)=\frac{\text { Weight } \text { of crude fibre }}{\text { Original weight of sample }} \times 100$

\section{Estimation of total carbohydrates}

Total carbohydrates content was calculated by difference as follows: 
Total carbohydrates content $(\%)=100-$ $[$ Moisture $(\%)+$ Fat $(\%)+$ Ash $(\%)+$ Protein $(\%)+$ Crude fibre $(\%)]$

\section{Estimation of calorific value}

The calorific value in kilocalories (kcal) was calculated according to the Atwater system as follows:

Calorific value $(\mathrm{kcal})=(4 \mathrm{x}$ Protein content $)+$ $(9 \times$ Fat content $)+(4 \times$ Total carbohydrates content)

\section{Estimation of minerals}

$0.5 \mathrm{~g}$ of powdered samples of seeds, aerial parts and roots of garden cress were weighed and transferred to $100 \mathrm{~mL}$ conical flask. To this, $10 \mathrm{~mL}$ of diacid mixture of $\mathrm{HNO}_{3}$ and $\mathrm{HClO}_{4}$ in a ratio of $4: 1$ was added and the samples were allowed to stand overnight. The samples were heated on a hot plate gently at first and then vigorously until a clear colourless solution results or till white fumes ceased to come out. Samples were not heated to dryness. Heating was discontinued when the volume reduced to $2-3 \mathrm{~mL}$. The samples were cooled, transferred to $50 \mathrm{~mL}$ volumetric flask, made up to the mark by adding distilled water, filtered through Whatman no. 1 filter paper and used for the estimation of $\mathrm{Fe}, \mathrm{Cu}$, $\mathrm{Zn}$ and Mn using Varian AA240FS Fast Sequential Atomic Absorption Spectrophotometer (Agilent Technologies).

\section{Chemical analysis}

\section{Estimation of ascorbic acid}

Ascorbic acid was estimated by titrimetric method by following the method of Sadasivam and Manickam (1996). $5 \mathrm{~mL}$ of the working standard solution was pipetted out into a 100 $\mathrm{mL}$ conical flask, added $10 \mathrm{~mL}$ of $4 \%$ oxalic acid and titrated against the dye $\left(\mathrm{V}_{1} \mathrm{~mL}\right)$. End point was the appearance of pink colour which persisted for a few minutes. One gram of the powdered samples of seeds, aerial parts and roots of Garden cress were extracted in $4 \%$ oxalic acid by using centrifuge and made up to a known volume i.e. $100 \mathrm{~mL}$. $5 \mathrm{~mL}$ of the plant extracts was pipetted out into a $100 \mathrm{~mL}$ conical flask, added $10 \mathrm{~mL}$ of $4 \%$ oxalic acid and titrated against the dye $\left(\mathrm{V}_{2} \mathrm{~mL}\right)$. Ascorbic acid content was calculated as follows:

Amount of ascorbic acid $\mathrm{mg} / 100 \mathrm{~g}$ sample $=\frac{0.5 \mathrm{mg} \times \mathrm{V}_{2} \mathrm{~mL} \times 100 \mathrm{~mL}}{\mathrm{~V}_{1} \mathrm{~mL} \times 5 \mathrm{~mL} \times \mathrm{Wt} . \text { of the sample }} \times 100$

\section{Estimation of starch}

Starch was estimated by following the method of Sadasivam and Manickam (1996). $0.2 \mathrm{~g}$ of finely powdered samples of seeds, aerial parts and roots of garden cress were weighed and placed in $60 \mathrm{~mL}$ centrifuge tubes and added 20 $\mathrm{mL}$ of hot $80 \%$ alcohol to remove sugars. The tubes were then shaked for 5-10 min, centrifuged at $3000 \mathrm{rpm}$ for $10 \mathrm{~min}$ and supernatant was decanted. The residue was again extracted repeatedly with hot $80 \%$ alcohol until the supernatant was free of sugars as judged by negative test with anthrone reagent. The residue was cooled in ice water and added $5.0 \mathrm{~mL}$ of water and 6.5 $\mathrm{mL}$ of $52 \%$ perchloric acid while stirring the contents with a glass rod. It was allowed to stand for 15 min with occassional stirring, centrifuged and supernatant fractions were collected. The extraction step using perchloric acid was repeated 2-3 times. All the supernatants were collected; pooled and final volume was made up to $100 \mathrm{~mL}$ with water. Then $0.2 \mathrm{~mL}$ aliquot of the extract was taken and made up to $1 \mathrm{~mL}$ with water. After that, 4 $\mathrm{mL}$ freshly prepared anthrone reagent was added, mixed properly and the tubes were transferred to boiling water bath and heated for $8 \mathrm{~min}$. Then, the tubes were cooled rapidly under running tap water and the intensity of green to dark green colour was read at $630 \mathrm{~nm}$ using UV-Vis Double beam 
spectrophotometer Model 2203 (Systronics Co.) against a blank prepared similarly but containing respective solvent instead of extracts. A standard curve was prepared using 0 to $100 \mu \mathrm{g}$ glucose as per the procedure described above. Amount of glucose was calculated in the sample aliquots from the standard curve and multiplied by a factor 0.9 to arrive at the starch content.

\section{Estimation of tannins}

Tannins content was estimated as catechin equivalent by vanillin-hydrochloric acid method of Burns (1971). Five hundred mg of powdered samples of seeds, aerial parts and roots of garden cress was taken in a $50 \mathrm{~mL}$ test tube and $10 \mathrm{~mL}$ of methanol was added to it. The tubes were closed with pith corks. The contents of the tubes were shaken occasionally and allowed to stand overnight at 25 to $32^{\circ} \mathrm{C}$. One $\mathrm{mL}$ of clear supernatant was then pipetted in a test tube and $5 \mathrm{~mL}$ of vanillin- $\mathrm{HCl}$ reagent was added to it. The absorbance of brownish red colour so produced was measured at 525 $\mathrm{nm}$ after $25 \mathrm{~min}$ on a Spectronic 20 colorimeter. A blank containing methanol was also run simultaneously. A standard curve of catechin was prepared simultaneously in order to calculate amount of tannin.

\section{Estimation of total sugars}

Total sugars were estimated by the modified phenol sulphuric acid method of Dubois et al., (1956). For estimation of total sugars in aqueous extracts of seeds, aerial parts and roots of garden cress, $1.0 \mathrm{~mL}$ of each extract was diluted with respective solvent to adjust the absorbance within calibration limits. Then, $2.0 \mathrm{~mL}$ of phenol solution $(2 \%, \mathrm{w} / \mathrm{v})$ was added followed by $5.0 \mathrm{~mL}$ concentrated sulphuric acid. Acid was added in such a way that it directly pours on the solution. The test tubes were allowed to cool for $30 \mathrm{~min}$ and absorbance of the solution was measured at
490 nm using UV-Vis Double beam spectrophotometer Model 2203 (Systronics Co.) against a blank prepared similarly but containing respective solvent instead of extracts. The amount of total sugars present in the extracts was calculated from the standard curve of glucose and the results are expressed as milligrams per gram.

\section{Estimation of reducing sugars}

Reducing sugars were estimated by the method of Nelson (1944) as modified by Somogyi (1952). For estimation of reducing sugars in aqueous extracts of seeds, aerial parts and roots of garden cress, $1.0 \mathrm{~mL}$ of each extract was diluted with respective solvent to adjust the absorbance within calibration limits. Then, $1.0 \mathrm{~mL}$ distilled water was added, followed by addition of $1.0 \mathrm{~mL}$ alkaline copper reagent, solution was mixed, covered with aluminium foil and heated in boiling water bath for $20 \mathrm{~min}$. The tubes were cooled to room temperature and $1.0 \mathrm{~mL}$ of arsenomolybdate reagent was added.

The contents were mixed thoroughly and volume was made up to $10.0 \mathrm{~mL}$ with distilled water. The absorbance of the solution was measured at $520 \mathrm{~nm}$ using UV-Vis Double beam Spectrophotometer Model 2203 (Systronics Co.) against a blank prepared similarly but containing respective solvents instead of extracts. The amount of reducing sugars present in the extracts was calculated from the standard curve and the results are expressed as milligrams per gram.

\section{Estimation of non-reducing sugars}

The non-reducing sugars were calculated from the difference between the content of total sugars and that of reducing sugars.

Non-reducing sugars $=$ Total sugars Reducing sugars 


\section{Results and Discussion}

\section{Proximate composition}

The data of proximate composition of seeds, aerial parts and roots of garden cress of Hisar and Solan regions is given in Tables 1 and 2, respectively. Amongst different plant parts of garden cress (Hisar region and Solan region), moisture content ranged from $8.00-9.25 \%$ and $7.91-10.43 \%$, respectively; fat content ranged from $4.23-22.16 \%$ and 4.99 to $23.16 \%$, respectively; ash content ranged from $4.81-5.75 \%$ and $3.02-5.60 \%$, respectively; protein content ranged from $6.33-25.51 \%$ and $4.19-21.82 \%$, respectively; crude fibre content ranged from $10.83-32.90 \%$ and 10.70 - $31.83 \%$, respectively; total carbohydrates content ranged from $28.45-43.65 \%$ and $30.81-45.54 \%$, respectively; calorific value ranged from 234.55 - $415.31 \mathrm{kcal}$ and 243.85 $418.93 \mathrm{kcal}$, respectively. Present findings are in agreement with Al-Jasass and Al-Jasser (2012) who reported that crude fat content, ash content, crude protein content and crude fibre content in L. sativum seeds grown in Saudi Arabia was $23.19 \%, 7.1 \%, 24.19 \%$ and $11.9 \%$, respectively. Zia-Ul-Haq et al., (2012) reported that proximate analysis of $L$. sativum seeds indicated the presence of appreciable amounts of protein $(24.18 \%)$, fibre $(6.75 \%)$, lipids (28.03\%), ash (3.92\%), moisture (3.92\%) and carbohydrates (32.87\%).

\section{Mineral composition}

The data of mineral $(\mathrm{Fe}, \mathrm{Cu}, \mathrm{Zn}$ and $\mathrm{Mn}$ ) composition of seeds, aerial parts and roots of garden cress of Hisar and Solan regions is given in Tables 3 and 4, respectively.

\section{Iron $(\mathrm{Fe})$ content}

Fe content in seeds, aerial parts and roots of garden cress (Hisar region) was 92.37, 129.73 and $133.01 \mathrm{ppm}$, respectively (Table 3 ). The corresponding values of $\mathrm{Fe}$ content in garden cress (Solan region) were 98.60, 142.73 and $142.60 \mathrm{ppm}$, respectively (Table 4).

\section{Copper $(\mathrm{Cu})$ content}

$\mathrm{Cu}$ content in seeds, aerial parts and roots of garden cress (Hisar region) was 6.90, 3.40 and $5.70 \mathrm{ppm}$, respectively (Table 3 ).

The corresponding values of $\mathrm{Cu}$ content in garden cress (Solan region) were 6.03, 4.07 and $5.07 \mathrm{ppm}$, respectively (Table 4).

\section{Zinc (Zn) content}

$\mathrm{Zn}$ content in seeds, aerial parts and roots of garden cress (Hisar region) was 46.49, 34.70 and $25.28 \mathrm{ppm}$, respectively (Table 3 ). The corresponding values of $\mathrm{Zn}$ content in garden cress (Solan region) were 58.02, 29.05 and $25.37 \mathrm{ppm}$, respectively (Table 4).

\section{Manganese (Mn) content}

Mn content in seeds, aerial parts and roots of garden cress (Hisar region) was 33.30, 11.13 and $12.73 \mathrm{ppm}$, respectively (Table 3 ).

The corresponding values of $\mathrm{Mn}$ content in garden cress (Solan region) were 20.17, 12.27 and $12.45 \mathrm{ppm}$, respectively (Table 4).

Similar findings have also been reported by other research workers. Sat et al., (2013) reported that $\mathrm{Fe}, \mathrm{Cu}, \mathrm{Zn}$ and $\mathrm{Mn}$ content in leaves of two garden cress cultivars viz. Dadas and Izmir cultivated in Turkey ranged from 47.21 to $45.94 \mathrm{mg} / \mathrm{kg}$, from 26.16 to 28.33 $\mathrm{mg} / \mathrm{kg}, 92.30$ to $118.80 \mathrm{mg} / \mathrm{kg}$ and from 74.20 to $62.01 \mathrm{mg} / \mathrm{kg}$, respectively.

Solomon et al., (2016) reported 11.30 $\mathrm{mg} / 100 \mathrm{~g}$ Fe content and $1.85 \mathrm{mg} / 100 \mathrm{~g} \mathrm{Mn}$ content in $L$. sativum seeds collected from Eastern Ethiopia. 
Table.1 Proximate composition of seeds, aerial parts and roots of Garden cress (Hisar region)

\begin{tabular}{|c|c|c|c|c|}
\hline $\begin{array}{l}\text { Plant and } \\
\text { Location }\end{array}$ & Parameter & Seeds & Aerial Parts & Roots \\
\hline \multirow{7}{*}{$\begin{array}{c}\text { Garden } \\
\text { cress } \\
\text { (Hisar) }\end{array}$} & Moisture (\%) & $8.09 \pm 0.02$ & $9.25 \pm 0.08$ & $8.00 \pm 0.10$ \\
\hline & Fat $(\%)$ & $22.16 \pm 0.07$ & $6.69 \pm 0.06$ & $4.23 \pm 0.09$ \\
\hline & $\operatorname{Ash}(\%)$ & $4.96 \pm 0.05$ & $4.81 \pm 0.04$ & $5.75 \pm 0.24$ \\
\hline & Protein (\%) & $25.51 \pm 0.52$ & $8.77 \pm 0.25$ & $6.33 \pm 0.13$ \\
\hline & Crude fibre (\%) & $10.83 \pm 0.52$ & $26.83 \pm 1.35$ & $32.90 \pm 0.55$ \\
\hline & Total carbohydrates $(\%)$ & $28.45 \pm 0.89$ & $43.65 \pm 1.64$ & $42.79 \pm 0.82$ \\
\hline & Calorific value (kcal) & $415.31 \pm 1.73$ & $269.89 \pm 6.11$ & $234.55 \pm 2.38$ \\
\hline
\end{tabular}

Table.2 Proximate composition of seeds, aerial parts and roots of Garden cress (Solan region)

\begin{tabular}{|c|l|c|c|c|}
$\begin{array}{c}\text { Plant and } \\
\text { Location }\end{array}$ & Parameter & Seeds & A erial Parts & Roots \\
\hline $\begin{array}{c}\text { Garden } \\
\text { cress }\end{array}$ & Moisture (\%) & & & \\
(Solan) & Ash (\%) & $7.91 \pm 0.08$ & $9.13 \pm 0.02$ & $10.43 \pm 0.04$ \\
\cline { 2 - 5 } & Protein (\%) & $23.16 \pm 0.13$ & $8.98 \pm 0.22$ & $4.99 \pm 0.06$ \\
\hline & Crude fibre (\%) & $21.82 \pm 0.05$ & $3.44 \pm 0.03$ & $3.02 \pm 0.07$ \\
\cline { 2 - 5 } & Total carbohydrates (\%) & $10.70 \pm 0.68$ & $2.21 \pm 0.13$ & $4.19 \pm 0.38$ \\
\hline & Calorific value (kcal) & $418.93 \pm 3.53$ & $291.27 \pm 0.23$ & $31.83 \pm 0.43$ \\
\hline
\end{tabular}

Table.3 Minerals content (ppm) in seeds, aerial parts and roots of Garden cress (Hisar region)

\begin{tabular}{|c|c|c|c|c|}
\hline \multirow{2}{*}{$\begin{array}{l}\text { Plant } \\
\text { and } \\
\text { Location }\end{array}$} & \multirow{2}{*}{$\begin{array}{l}\text { Minerals } \\
\downarrow \text { Plant Part } \longrightarrow\end{array}$} & \multicolumn{3}{|c|}{ Mineral content (ppm) } \\
\hline & & Seeds & Aerial Parts & Roots \\
\hline \multirow{4}{*}{$\begin{array}{c}\text { Garden } \\
\text { cress } \\
\text { (Hisar) }\end{array}$} & $\mathbf{F e}$ & $92.37 \pm 4.09$ & $129.73 \pm 2.79$ & $133.01 \pm 4.37$ \\
\hline & $\mathbf{C u}$ & $6.90 \pm 0.06$ & $3.40 \pm 0.06$ & $5.70 \pm 0.12$ \\
\hline & $\mathbf{Z n}$ & $46.49 \pm 6.30$ & $34.70 \pm 1.00$ & $25.28 \pm 1.61$ \\
\hline & Mn & $33.30 \pm 1.08$ & $11.13 \pm 0.19$ & $12.73 \pm 0.72$ \\
\hline
\end{tabular}

Table.4 Minerals content (ppm) in seeds, aerial parts and roots of Garden cress (Solan region)

\begin{tabular}{|c|c|c|c|c|}
\hline \multirow{2}{*}{$\begin{array}{l}\text { Plant } \\
\text { and } \\
\text { Location }\end{array}$} & \multirow{2}{*}{$\begin{array}{l}\text { Minerals } \\
\downarrow \text { Plant Part } \longrightarrow\end{array}$} & \multicolumn{3}{|c|}{ Mineral content (ppm) } \\
\hline & & Seeds & Aerial Parts & Roots \\
\hline \multirow{4}{*}{$\begin{array}{c}\text { Garden } \\
\text { cress } \\
\text { (Solan) }\end{array}$} & $\mathbf{F e}$ & $98.60 \pm 1.47$ & $142.73 \pm 1.01$ & $142.60 \pm 6.54$ \\
\hline & $\mathbf{C u}$ & $6.03 \pm 0.09$ & $4.07 \pm 0.24$ & $5.07 \pm 0.28$ \\
\hline & $\mathbf{Z n}$ & $58.02 \pm 2.47$ & $29.05 \pm 0.83$ & $25.37 \pm 0.58$ \\
\hline & Mn & $20.17 \pm 0.12$ & $12.27 \pm 0.15$ & $12.45 \pm 0.16$ \\
\hline
\end{tabular}


Table.5 Chemical composition of seeds, aerial parts and roots of Garden cress (Hisar region)

\begin{tabular}{|c|c|c|c|c|}
\hline $\begin{array}{l}\text { Plant } \\
\text { and } \\
\text { Location }\end{array}$ & Parameter & Seeds & Aerial Parts & Roots \\
\hline \multirow{6}{*}{$\begin{array}{c}\text { Garden } \\
\text { cress } \\
\text { (Hisar) }\end{array}$} & Ascorbic acid (mg/100g) & $49.75 \pm 0.74$ & $84.28 \pm 0.50$ & $19.08 \pm 0.53$ \\
\hline & Starch $(\mathrm{mg} / \mathrm{g})$ & $13.77 \pm 0.42$ & $23.03 \pm 0.73$ & $11.90 \pm 0.31$ \\
\hline & Tannins (mg/g) & $3.94 \pm 0.04$ & $3.16 \pm 0.06$ & $1.28 \pm 0.04$ \\
\hline & Total sugars (mg/g) & $15.86 \pm 0.07$ & $33.04 \pm 0.07$ & $14.35 \pm 0.08$ \\
\hline & Reducing sugars (mg/g) & $2.58 \pm 0.09$ & $3.27 \pm 0.07$ & $1.78 \pm 0.09$ \\
\hline & Non-reducing sugars (mg/g) & $13.28 \pm 0.02$ & $29.77 \pm 0.04$ & $12.57 \pm 0.12$ \\
\hline
\end{tabular}

Table.6 Chemical composition of seeds, aerial parts and roots of Garden cress (Solan region)

\begin{tabular}{|c|l|c|c|c|}
$\begin{array}{c}\text { Plant } \\
\text { and } \\
\text { Location }\end{array}$ & \multicolumn{1}{|c|}{ Parameter } & Seeds & A erial Parts & Roots \\
\hline $\begin{array}{c}\text { Garden } \\
\text { cress } \\
\text { (Solan) }\end{array}$ & Ascorbic acid (mg/100g) & $43.80 \pm 0.33$ & $77.59 \pm 0.84$ & $14.58 \pm 0.54$ \\
& Starch (mg/g) & $10.37 \pm 0.20$ & $19.51 \pm 0.54$ & $6.86 \pm 0.35$ \\
& Tannins (mg/g) & $3.67 \pm 0.06$ & $2.93 \pm 0.04$ & $1.10 \pm 0.04$ \\
\hline & Total sugars (mg/g) & $13.52 \pm 0.06$ & $30.87 \pm 0.13$ & $12.40 \pm 0.08$ \\
\hline & $\begin{array}{l}\text { Reducing sugars (mg/g) } \\
\text { Non-reducing Sugars } \\
\text { (mg/g) }\end{array}$ & $1.52 \pm 0.09$ & $3.00 \pm 0.06$ & $1.02 \pm 0.03$ \\
\hline
\end{tabular}

\section{Chemical composition}

The data of chemical composition of seeds, aerial parts and roots of garden cress of Hisar and Solan regions is given in Tables 5 and 6, respectively.

\section{Ascorbic acid content}

Amongst different plant parts of garden cress (Hisar region), ascorbic acid content $(\mathrm{mg} / 100 \mathrm{~g})$ was highest in aerial parts $(84.28)$ followed by in seeds (49.75) and roots (19.08) (Table 5). Similarly, in garden cress of Solan region, ascorbic acid content $(\mathrm{mg} / 100 \mathrm{~g})$ was highest in aerial parts (77.59) followed by in seeds (43.80) and roots (14.58) (Table 6). The findings of present studies are in accordance with Sat et al., (2013) who reported that ascorbic acid content in leaves of two garden cress cultivars viz. Dadas and Izmir cultivated in Turkey was 54 and $74 \mathrm{mg} / 100 \mathrm{~g}$.

\section{Starch content}

In garden cress (Hisar region), amongst different parts starch content $(\mathrm{mg} / \mathrm{g})$ was highest in aerial parts (23.03) followed by in seeds (13.77) and roots (11.90) (Table 5). Similarly, in garden cress of Solan region, starch content $(\mathrm{mg} / \mathrm{g})$ was highest in aerial parts (19.51) followed by in seeds (10.37) and roots (6.86) (Table 6). However, no literature is available on starch content in Garden cress.

\section{Tannins content}

Amongst different parts of garden cress (Hisar region), tannins content $(\mathrm{mg} / \mathrm{g})$ was 
highest in seeds (3.94) followed by in aerial parts (3.16) and roots (1.28) (Table 5). Similarly, in garden cress of Solan region, tannins content $(\mathrm{mg} / \mathrm{g})$ was highest in seeds (3.67) followed by in aerial parts (2.93) and roots (1.10) (Table 6). Other research workers have also reported tannins content in similar range. Hussain et al., (2011) reported $0.61 \%$ tannins content in L. sativum. Tannins content in whole garden cress seed flour was 51.0 $\mathrm{mg} / 100 \mathrm{~g}$ (Agarwal and Sharma, 2013).

\section{Total sugars content}

In garden cress (Hisar region), amongst different plant parts total sugars content $(\mathrm{mg} / \mathrm{g})$ was highest in aerial parts (33.04) followed by in seeds (15.86) and roots (14.35) (Table 5). Similarly, in garden cress of Solan region, total sugars content $(\mathrm{mg} / \mathrm{g})$ was highest in aerial parts (30.87) followed by in seeds (13.52) and roots (12.40) (Table 6).

\section{Reducing sugars content}

In garden cress (Hisar region), reducing sugars content $(\mathrm{mg} / \mathrm{g})$ was highest in aerial parts (3.27) followed by in seeds (2.58) and roots (1.78) (Table 5). Similarly, in garden cress of Solan region, reducing sugars content $(\mathrm{mg} / \mathrm{g})$ was highest in aerial parts (3.00) followed by in seeds (1.52) and roots (1.02) (Table 6).

\section{Non-reducing sugars content}

Amongst different parts of garden cress (Hisar region), non-reducing sugars content (mg/g) was highest in aerial parts (29.77) followed by in seeds (13.28) and roots (12.57) (Table 5). Similarly, in garden cress of Solan region, non-reducing sugars content $(\mathrm{mg} / \mathrm{g})$ was highest in aerial parts (27.87) followed by in seeds (12.00) and roots (11.38) (Table $6)$.
All parts viz. seeds, aerial parts and roots of garden cress collected from two different locations i.e. Hisar and Solan possessed good proximate and mineral composition. On the basis of calorific values, all parts were found to be very rich source of energy. Seeds, aerial parts and roots of garden cress (Hisar and Solan regions) were also found to be good source of ascorbic acid, starch, tannins, total sugars, reducing sugars and non-reducing sugars. Hence, due to good proximate, mineral and chemical composition, garden cress plant as a whole including seeds, aerial parts and roots or its different parts would be of significant importance in pharmaceutical formulations.

\section{References}

Agarwal, N. and Sharma, S. 2013. Appraisal of garden cress (Lepidium sativum L.) and product development as an all pervasive and nutrition worthy food stuff. Annals of Food Science and Technology, 14(1): 77-84.

Ahamad, R., Mujeeb, M., Anwar, F. and Ahmad, A. 2015. Phytochemical analysis and evaluation of anti-oxidant activity of methanolic extract of Lepidium sativum L. seeds. Der Pharmacia Lettre, 7(7): 427-434.

Al-Jasass, F. M. and Al-Jasser, M. S. 2012. Chemical composition and fatty acid content of some spices and herbs under Saudi Arabia conditions. The Scientific World Journal, 2012: 1-5.

Al-Yahya, M. A., Mossa, J. S., Ageel, A. M. and Rafatullah, S. 1994 Pharmacological and safety evaluation studies on Lepidium sativum L., seeds. Phytomedicine, 1(2): 155-159.

Burns, R. E. 1971. Method for estimation of tannin in grain sorghum. Agronomy Journal, 63: 511-512.

Dubois, M., Gilles, K. A., Hamilton, J. K., Rubers, P. A. and Smith, F. 1956. 
Colorimetric method for determination of sugar and related substances. Analytical Chemistry, 28(3): 350-356.

Hussain, I., Khattak, M. U. R., Ullah, R., Muhammad, Z., Khan, N., Khan, F. A., Ullah, Z. and Haider, S. 2011. Phytochemicals screening and antimicrobial activities of selected medicinal plants of Khyberpakhtunkhwa Pakistan. African Journal of Pharmacy and Pharmacology, 5(6): 746-750.

Manohar, D., Viswanatha, G. L., Nagesh, S., Jain, V. and Shivaprasad, H. N. (2012). Ethnopharmacology of Lepidium sativum Linn (Brassicaceae): A review. International Journal of Phytothearpy Research, 2(1): 1-7.

Maynard, A. J. 1970. Method in Food Analysis, pp. 176. Academic Press, New York.

Nelson, N. 1944. A photometric adaptation of the Somogyi method for determination of glucose. Journal of Biological Chemistry, 153: 375-380.

Phillipson, J. D. 2007. Phytochemistry and pharmacognosy. Phytochemistry, 68(22) : 2960-2972.

Sadasivam, S. and Manickam, A. 1996. Biochemical Methods, pp. 11, 184. New
Age International (P) Limited, Publishers, New Delhi.

Sat, I. G., Yildirim, E., Turan, M. and Demirbas, M. 2013. Antioxidant and nutritional characteristics of garden cress (Lepidium sativum). Acta Scientiarum Polonorum Hortorum Cultus, 12(4): 173-179.

Sharma, S. and Agarwal, N. 2011. Nourishing and healing prowess of garden cress (Lepidium sativum Linn.) - A review. Indian Journal of Natural Products and Resources, 2(3): 292-297.

Solomon, G., Aman, D. and Bachheti, R. K. 2016. Fatty acids, metal composition, nutritional value and physicochemical parameters of Lepidium sativium seed oil collected from Ethiopia. International Food Research Journal, 23(2): 827-831.

Somogyi, M. 1952. Notes on sugar determination. Journal of Biological Chemistry, 195: 19-23.

Zia-Ul-Haq, M., Ahmad, S., Calani, L., Mazzeo, T., Rio, D. D., Pellegrini, N. and Feo, V. D. 2012. Compositional study and antioxidant potential of Ipomoea hederacea Jacq. and Lepidium sativum L. seeds. Molecules, 17: 1030610321.

\section{How to cite this article:}

Satya Shree Jangra and Vinod Kumar Madan. 2018. Phytochemical and Nutritional Composition of Different Parts of Garden Cress (Lepidium sativum L.). Int.J.Curr.Microbiol.App.Sci. 7(11): 1136-1145. doi: https://doi.org/10.20546/ijcmas.2018.711.132 